\title{
ANTIMICROBIAL ACTIVITY OF ALUMINA NANOPARTICLES SYNTHESIZED BY LEAF EXTRACT OF OCIMUM SANCTUM
}

\author{
Preeti Sharma \\ Department of Physics \\ Agra College, Agra, U.P., India
}

\author{
Neera Sharma \\ Department of Physics \\ Agra College, Agra, U.P., India
}

\begin{abstract}
In this research article, we synthesized Alumina nanoparticles using leaf extract of Ocimum Sanctum. We have characterized synthesized nanoparticles using FESEM, DLS and EDS analysis. We have also investigated antimicrobial activity of the Alumina nanoparticles using disc diffusion method against gram positive and gram negative bacteria. It is comcluded that Alumina nanoparticles are successfully synthesized using leaf extract of Ocimum Sanctum and they are spherical in shape. It is also concluded that these Alumina nanoparticles are good antimicrobial agents against both gram positive and gram negative bacteria.
\end{abstract}

Key words - Alumina nanoparticles, FESEM, DLS, EDS, Antimicrobial activity.

\section{INTRODUCTION}

During last few years researchers are trying to use nanotechnology in every field of life and study. Due to very high surface to volume ratio and unique chemical and physical properties, nanoparticlescan be used for wide number of applications. Physico - chemical properties play an important role in anti microbial activity of nanoparticles and we know that nanoparticles show properties very much different from their bulk counterparts. Therefore, nanoparticles are emerged as novel anti microbial agents [1]. Morones J.R. et al (2005) observed that nanoparticles can change the properties of bacterial cell membrane, can damage DNA of bacteria and release toxic ions to damage bacteria [2]. Dutta R.K. et al (2012) shows their interest in inorganic nanoparticles as antimicrobial agents as they are ecofriendly and more stable than previously used organic antimicrobial agents [3]. Varghese N. et al (2014) concluded that Alumina nanoparticles are thermally stable over a wide range of temperature. They stated that Alumina nanoparticles have corundum like structure with oxygen atoms having hexagonal closed packing and Aluminium ions filling two - third of octahedral sites in the lattice [4]. Ruparelia J.P. et al (2008), Hameed A.S.H. et al (2016) and Mitoraj D. et al (2007) clarified that nanoparticles show antimicrobial activity against $\mathrm{E}$, coli and styphylococcus aureus bacteria [5, 6, and 7]. In this research article, attempts have been made to investigate anti microbial activity of Alumina nanoparticles synthesized by green method on gram positive and gram negative bacteria.

\section{EXPERIMENTAL PROCEDURE}

We prepared extract of Ocimum Sanctum. The prepared extract was stored at $4{ }^{\circ} \mathrm{C}$. The solution of Aluminium nitrate was prepared. Then, plant extract was mixed with solution of salt and constantly stirred with the help of magnetic stirrer. Obtained precipitate is filtered using filter paper. The detailed experimental procedure is described elsewhere [8].

FESEM studies are carried out on Hitachi - PU model operating at resolution from $100 \mathrm{~nm}$ to $1.0 \mu \mathrm{m}$ at an accelerating voltage $5.0 \mathrm{KV}$ and magnification 25000 to 180000.The hydrodynamic size of Alumina nanoparticles is determined by differential light scattering (DLS). For this purpose, nanoparticles were sonicated in water at $25^{\circ} \mathrm{C}$ temperature.

The antimicrobial activity of Alumina nanoparticles is investigated by Disc diffusion method against two bacteria E. coli and staphylococcus aureus. The antimicrobial activity is investigated for five different concentrations $6.25 \mathrm{mg} / \mathrm{mL}, 12.5 \mathrm{mg} / \mathrm{mL}, 25 \mathrm{mg} / \mathrm{mL}, 50$ $\mathrm{mg} / \mathrm{mL}$ and $100 \mathrm{mg} / \mathrm{mL}$.

\section{CHARACTERIZATION}

\section{A. FESEM Analysis}

The surface morphological analysis of the nanoparticles is done by FESEM. SEM micrographs (Fig.1) indicate that Alumina nanoparticles synthesized by this method are spherical. 


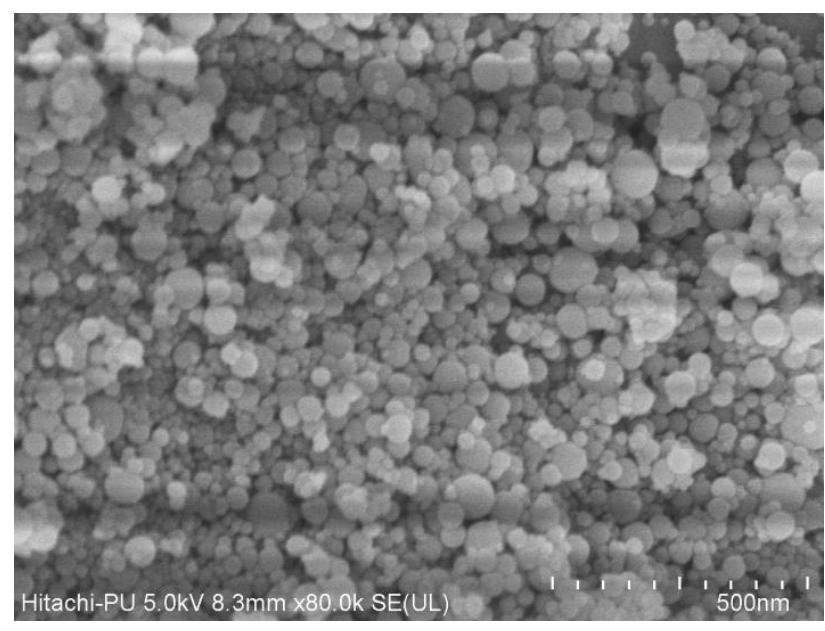

Fig. 1 FESEM image of Alumina nanoparticles

\section{B. DLS Analysis}

To determine hydrodynamic size, size distribution by intensity is plotted (Fig.2). Peak is obtained at $96.10 \mathrm{~nm}$ with standard deviation $48.73 \mathrm{~nm}$. This result is compatible with the result obtained by XRD and HRTEM.

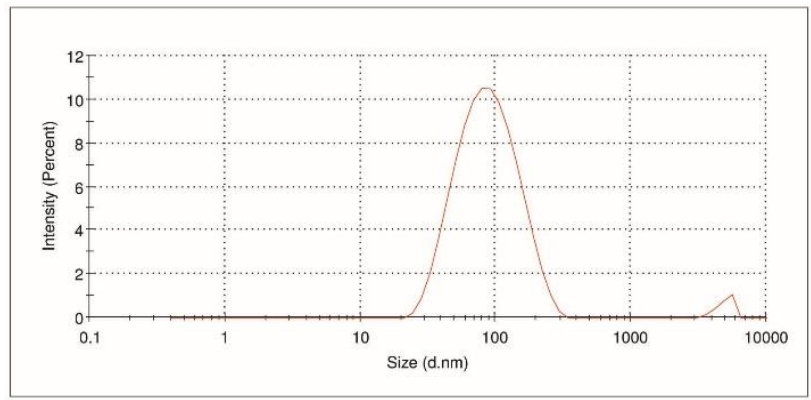

Fig. 2 DLS image of Alumina nanoparticles

\section{EDS Analysis}

Quantitative analysis of Alumina nanoaprticles is done by Energy Dispersive Spectroscopy (EDS). From EDS (Fig.3), it is clear that $\mathrm{Al}$ and $\mathrm{O}$ are major components of the prepared sample and rests are present as impurity. This confirms the formation of Alumina nanoparticles by this method.

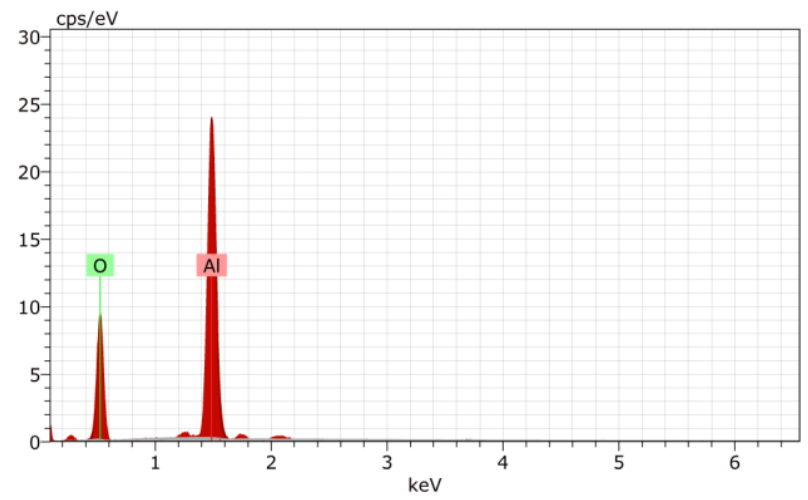

Fig.3 EDS image of Aluminium oxide nanoparticles

\section{ANTIMICROBIAL ACTIVITY OF ALUMINA NANOPARTICLES}

Disc diffusion method is used to investigate antimicrobial activity of Alumina nanoparticles. The antimicrobial activity is investigated against two microorganisms, E. colis and staphylococcus aureus. The media used for this purpose was MaeConkey Agar (Fig.4) and Nutrient Agar (Fig.5). Simultaneously the standard antibiotic gentamycin is tested against the pathogens. We can see that as concentration increases, zone of inhibition also increases.

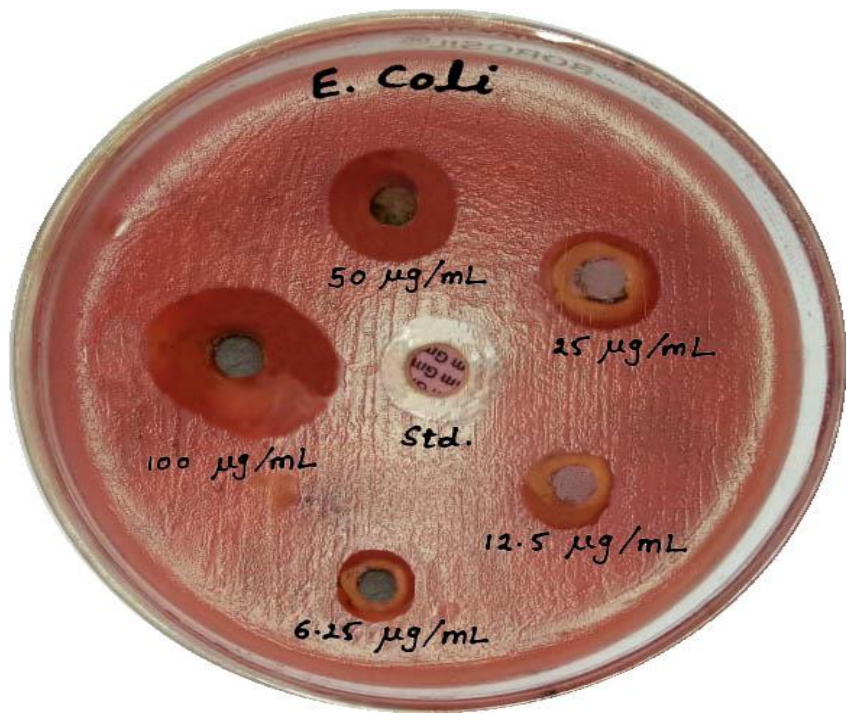

Fig.4 Antimicrobial activity of Aluminium oxide nanoparticles against E. Coli in media Maeconny Agar

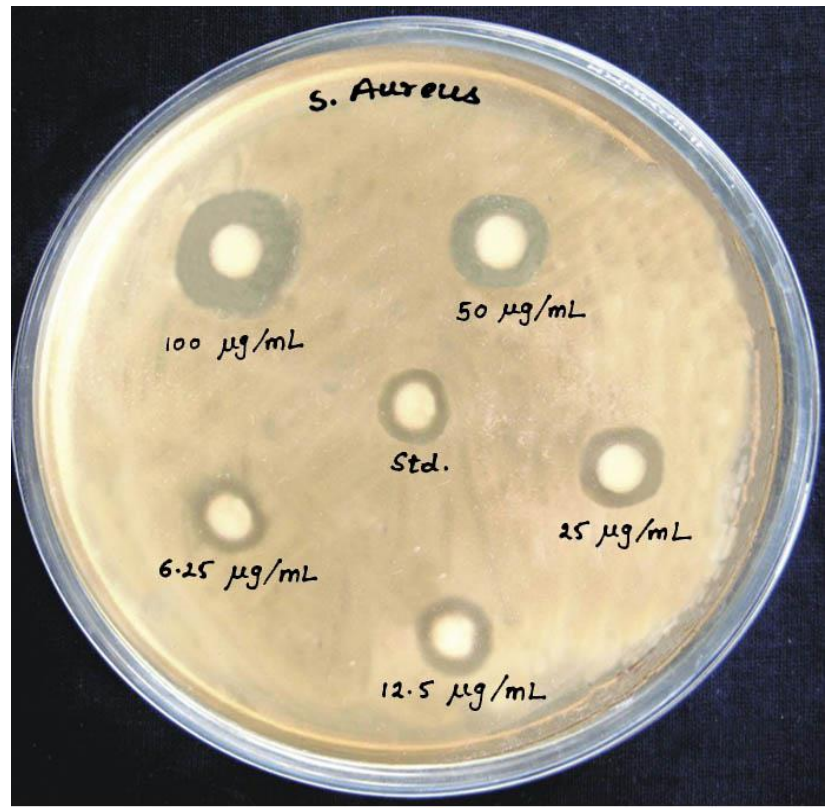


Fig.5 Antimicrobial activity of Aluminium oxide anaoparticles against $\mathrm{S}$. aureus in media neutriant agar

The result shows that Alumina nanoparticles synthesized by leaf extract of Ocimum Sanctum have effective antimicrobial activity against pathogenic bacteria.

\section{CONCLUSION}

From this research work, it is concluded that Alumina nanoparticles synthesized by leaf extract of Ocimum Sanctum are showed antimicrobial activity against both gram positive and gram negative bacteria.Formation of zone of inhibition confirms that these nanoparticles are good antimicrobial agents.

\section{REFERENCES}

[1] Chandrika R. K., Kiranmayi P., Ravikumar R.V.S.S.N. (2012). Synthesis, Characterization and Antibacterial Activity of $\mathrm{ZnO}$ Nanoparticles. Int J Pharm Sci; 4, (pp $336-338)$.

[2] Morones J. R., Elechiguerra J. L., Camacho A., Holt K., Kouri J. B., Ramirez J. T., M. Yacaman J., (2005), The Bactericidal Effect of Silver Nanoparticles, Nanotechnology, 16,(pp. 2346-2353)
[3] Dutta R.K., Nenavathu B.P., Gangishetty M.K., Reddy A.V.R., (2012), Studies on Antimicrobial Activity of $\mathrm{ZnO}$ Nanoparticles by ROS Induced Lipid Peroxidation, Colloid.Surf. B. Biointerfaces 94, (pp143150)

[4] Varghese N., Hariharan M., Cherian B. A., Sreenivasan PV, Paul J., (2014), PVA-Assisted synthesis and characterization of nano $\alpha$-alumina. Int J Sci Res; 4 , (pp 1-4).

[5] Ruparelia J. P., Chatterjee A. K., Duttagupta S. P., Mukherji S., (2008), Strain Specificity in Antimicrobial Acitvity of Silver and Copper Nanoparticles, Acta Biomater.,4 (3), (pp 707-716)

[6] Hameed A. S. H., Karthikeyan C., Ahamed A. P., Thajuddin N., Alharbi N.S., Alharbi S.A., Ravi G., (2016), In vitro Antimicrobial Activity of $\mathrm{ZnO}$ and $\mathrm{Nd}$ doped $\mathrm{ZnO}$ Nanoparticles Against ESBL producing Escherichia coli and Klebsiella Pneumoniae, Sci. Rep., 6, (pp 1-11).

[7] Mitoraj D., Jańczyk A., Strus M., Kisch H., Stochel G., Heczko P. B., Macyk W., (2007), Visible Light Inactivation of Bacteria and Fungi by Modified Titanium Dioxide, Photochem. Photobiol. Sci., 6, (pp 642-648)

[8] Sharma P., Sharma N., (2019), Optical Properties of Aluminium Oxide Nanoparticles Synthesized by Leaf Extract of Ocimum Sanctum, J. Nanosci. Tech., Vol. 5 (4), $\quad\left(\begin{array}{llll}\text { (pp } & 817 & - & 819\end{array}\right)$. 